\title{
THE LEGAL FRAMEWORK FOR DOING BUSINESS IN RUSSIA: A SUMMARY*
}

\author{
PAUL DRAGER
}

The Canadian oil and gas industry has been particularly successful in establishing operations in Russia. The author argues that the Canadian penetration of Russia's byzantine legislation, regulation and bureaucracy is due to Canada's long history of governmental and commercial dealings with the former Soviet Union; to Canada's relatively low profile on the international political scene; and to the fact that those involved in the petroleum industries in Canada and Russia share similar experiences in terms of the problems posed by climate, geology and jurisdictional overlap in both countries, experiences which have led to mutual understanding and enhanced co-operation. The author provides an overview of the issues and options which confront a Canadian company in the process of establishing a viable operation in Russia. He suggests that patience, flexibility and long-term planning are the management tools required to succeed in Russia's fluid and complex legal and legislative environment.

\section{TABLE OF CONTENTS}

I. INTRODUCTION $\ldots \ldots \ldots \ldots \ldots \ldots \ldots \ldots \ldots \ldots \ldots \ldots \ldots \ldots \ldots \ldots$

II. VENTURING INTO RUSSIA $\ldots \ldots \ldots \ldots \ldots \ldots \ldots \ldots \ldots 311$

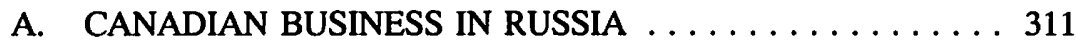

B. GOVERNMENT SUPPORT $\ldots \ldots \ldots \ldots \ldots \ldots \ldots \ldots 312$

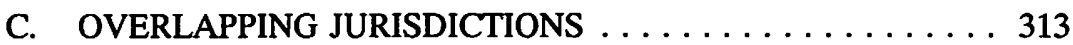

III. LEGAL REGIMES FOR CORPORATE

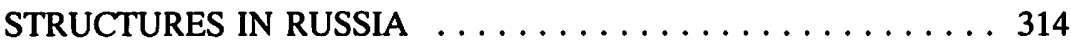

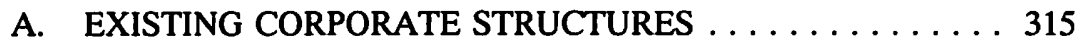

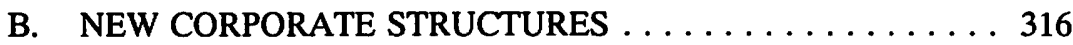

IV. CREATION OF A JOINT STOCK COMPANY $\ldots \ldots \ldots \ldots \ldots 318$

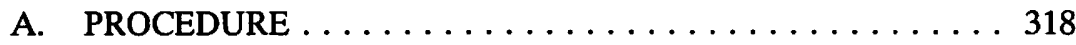

B. HOW TO ESTABLISH THE DEAL ........... 319

C. LOCAL GOVERNMENT REGULATIONS ......... 320

D. RUSSIAN FEDERATION

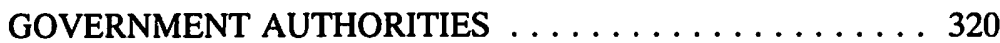

V. THE RUSSIAN TAX FRAMEWORK $\ldots \ldots \ldots \ldots \ldots \ldots \ldots 321$

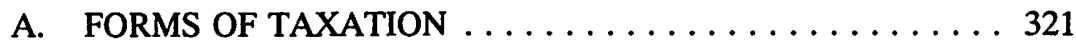

B. TAX CONSIDERATIONS WHEN

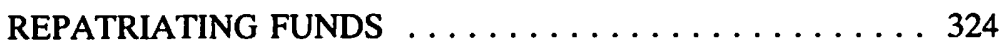

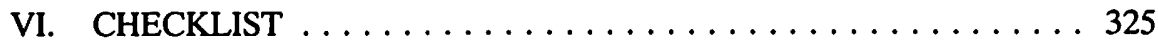

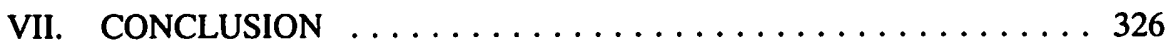

This summary was correct as of the fall of 1993. Significant political and legal changes occurred in the fall and winter of 1993. Russia continues to be a fluid system in 1994.

-. Partner, Macleod Dixon, Calgary. The author wishes to acknowledge the assistance he received from Ms. Joanne Cox, Associate Lawyer, Macleod Dixon, in the preparation of this paper. 


\section{INTRODUCTION}

The following paper is an overview of Canadian efforts at penetrating the Russian oil and gas industry and a synopsis of the various legal forms which Canadian business can adopt as foreign investors and participants in the former Soviet Union.

Legal forms in Russia are constantly evolving. Each Canadian venture has been required to adopt a flexible and unique approach to establish its rights, whether contractual or as a joint venture partner, in this new environment. Coping with all the uncertainties of the past seven years since initial permission was granted for foreign equity investment in the former Soviet Union, Canadian business has shown by initiative and foresight that, based on what are now being viewed as precedent setting business forms, success is possible in an emerging petroleum industry in Russia.

\section{VENTURING INTO RUSSIA}

\section{A. CANADIAN BUSINESS IN RUSSIA}

Canadian business investment in Russia and the other republics of the former Soviet Union has been recognized as having a greater success ratio than investment from many other countries. A recent study undertaken by the Canada-Russia Business Council ("CUBC") indicated that Canadian joint ventures compare well against those from Western Europe. According to this study, Canadian joint ventures appear in a wider variety of commercial sectors, have a greater average investment per venture, are registered faster, employ more people on aggregate and are to a far greater extent operational than the majority of other joint ventures established in the former USSR by companies from other countries. ${ }^{1}$ As Lou Namouvski, formerly the executive director of the CUBC and presently in Moscow with the European Bank for Reconstruction and Development ("EBRD"), stated in Canada-USSR Joint Ventures, A Survey and Analytical Review, "[Canadians succeed] in spite of the well documented familiarity and experience of German and Finnish companies with the USSR market. Canadian business should take pride in this remarkable development." ${ }^{12}$ Canadians have been able to achieve success where others have bogged down.

Canadian firms have been able to build upon a bilateral trading relationship that commenced with large grain sales to the USSR in the 1970s and 1980s. With the USSR already an important trading partner in terms of gross sales, the Canadian government was eager to diversify this relationship. The Canada-Russia trade infrastructure already included a treaty to avoid double taxation ${ }^{3}$ a foreign investment protection agreement ${ }^{4}$,

1 Canada-USSR Business Council, Canada-USSR Joint Ventures, A Survey and Analytical Review, (Toronto: 1991). For an in-depth review of the Canadian business experience in Russia, covering such topics as the profiles of Canadian-Soviet joint ventures, the nature of the parties, the negotiation process, etc., a copy of the survey should be procured from the Canada-Russia Business Council. lbid.

Canada-USSR Agreement for the Avoidance of Double Taxation on Income, S.C. 1986, c. 7. 
as well as regular government-to-government contacts on commercial matters. This provided a framework within which Canadian companies were able to commit further investments, from projects in agriculture to those in construction and the energy sector.

Particularly in the energy sector, it became apparent to companies such as SNCLavalin, Canadian Fracmaster and Canadian Foremost that if one could learn to accept the elements of political change and instability, the fundamental aspects of investing in this area would provide ever-increasing opportunities.

Cold weather oil and gas technologies developed in Canada had immediate application in the Russian energy sector. The similarities of climate, distances to market, harsh operating conditions and even reserve characteristics made the technical side of the business deal substantially easier to negotiate as the Canadian technical teams could understand quickly the real requirements of the oilmen in the field. In all the negotiations in which the writer has taken part, it has been apparent that language and cultural barriers were broken down, in large measure, due to the technical side's compatibility with their Russian counterparts, and not necessarily due to the efforts of the business team. The technical congruity raised levels of trust and provided a firm basis on which to negotiate the myriad of business issues.

Canadian companies had another advantage, although one not so immediately apparent. Canada, though a member of the $\mathrm{G} 7$ and an active participant on the international scene, is not a major world power. Canadian business, therefore, is not burdened with an excessively high political profile, which can often complicate the inherent bureaucratic delays one must work through in the Commonwealth of Independent States ("CIS") and its constituent parts. This has led to a number of international companies utilizing their Canadian subsidiaries as vehicles to enter the CIS market - McDonald's Canada being a case in point.

\section{B. GOVERNMENT SUPPORT}

Canadian government support has often played a role in smoothing the road for Canadian business. In dealing with the omnipresent Russian bureaucracy, Canadian firms have often used the informal political route to gain access to the important decision makers in the various republics. Substantial assistance has been forthcoming from such government sources as Renaissance Eastern Europe, the Task Force on Central and Eastern Europe and External Affairs. These programs have provided funding for such private sector initiatives as the organization of the CUBC, with its oil and gas subsection based in Calgary. There has also been effective support from the Canadian Embassy in Moscow. The Canadian government expended substantial efforts to achieve the signing of the Declaration of Friendship and Cooperation on February 1, 1992, its purpose, in part, to create a favourable investment climate in Russia and to protect the Arctic environment. 
President Yeltsin's visits to Canada in July of 1992 and April of 1993 helped to strengthen relations between Canada and Russia. On both occasions, former Prime Minister Mulroney expressed political support for reforms in Russia and announced economic support as well. Most recently, Canada has committed to a Technical Assistance Program of $\$ 150$ million over five years which will encourage the establishment of Canada-Russia joint business ventures and support the modernization of Russia's oil and gas, northern and agricultural sectors.

The government is also supportive of private industry initiatives to assist the Russians in moving forward. For instance, Macleod Dixon has been advising the Russian Ministry of Foreign Economic Relations on international trade policy issues and the development of Russian trade and economic law, with the long term goal of assisting Russia in accession to the GATT. In connection with this project, in the summer of 1993, Russian trade officials visited Canada to meet with their counterparts in the Canadian government to study Canadian trade policy and the mechanics of federal-provincial relations with regard to multilateral trade issues.

The government has also been involved in the discussions on the European Energy Charter and the various protocols which will affect Canadian-Russian energy projects. This government support with the bilateral treaties provides the additional level of comfort required when making investment decisions related to the Russian energy sector.

\section{OVERLAPPING JURISDICTIONS}

One of the main problems with which energy companies are faced in the Russian Federation is the conflict between the various levels of governments. As Canadians, we often have an intuitive understanding for the difficulties of overlapping jurisdictional claims. The Canadian energy industry has faced multiple jurisdictional conflicts at home due to the decentralized federal structure of Canada. Canada has an energy rights management system that is responsive to local issues. In many frontier areas, the rights to explore for, develop and produce oil and gas are managed jointly by the federal and provincial governments. An understanding of multi-jurisdictional issues in the resource sector is crucial when dealing with regional governments in the Tyumen, Komi or Tartastan areas.

Canadian provincial governments have also recognized this structural parallel and have taken advantage of it, to the assistance of Canadian business. The government of Alberta, even prior to the breakup of the USSR, had a special intergovernmental relationship with the Russian Soviet Federated Socialist Republic ("RSFSR"). This led to numerous delegations from the Alberta energy industry arriving in Russia during the 1980s. It was the expertise and understanding of the Russian market gained from such visits, as well as the general cooperation of firms through industry associations, which produced a core of Canadian businessmen with an understanding of how to deal with the complexities of life and business in Russia and the other republics in the CIS. Most recently, the Alberta government has taken steps to establish a trade office in Tyumen. 
The former Canadian Minister of Energy, Mines and Resources, Mr. Jake Epp, recently commented during a visit to Moscow:

Canadian industry is leading the way among western nations. It is building on some 15 years of involvement in Russia's oil and gas sector with a renewed interest and a commitment to expanding its presence in Russia. This is clearly reflected in the fact that close to a dozen cooperative ventures are now under way between Canadian and Russian industries. Three of those joint ventures involve Canadian Fracmaster, the firm that pioneered the concept of production-sharing joint venture agreements and is the leading western energy company operating in Russia today. Other Canadian companies involved in joint ventures with Russian industry include Gulf Canada Resources, Norcen Energy Resources, PanCanadian Petroleum, Canadian Foremost, Wega-D Geophysical and Lacey International. As well, the engineering firm SNC-Lavalin is managing a large gas field project in southern Russia and Hardy HBT is conducting environmental assessments of energy projects. Behind these Joint Ventures is the support of legal firms with Moscow offices such as Macleod Dixon.

Canadian businessmen presently active in Russia can advise investors on how to minimize time and expenses in setting up joint ventures (and other entities) in the former USSR. A 1991 Canadian study provided the following general advice for potential investors: 5

1. obtain knowledgeable advice/representation

2. choose Soviet/Russian partner carefully

3. be patient with your investment

4. research/clarify objectives and possibilities

5. adopt a long-term strategy

6. use the services of the Canadian-Russian Business Council

7. spend time in the former USSR to make detailed assessment

8. send only the most qualified representatives

9. deal at the federal level

Canadian businesses, with access to Western technology adapted for harsh climatic conditions, have successfully established a wealth of joint Canadian-Russian operations. Given basic stability and a continued acceptance of the fledgling mixed market economy, Canadian firms have indicated increased willingness to expand their efforts in the CIS in general and the Russian energy sector in particular.

\section{LEGAL REGIMES FOR CORPORATE STRUCTURES IN RUSSIA}

Under the present laws of the Russian Federation, particularly the Regulations Governing the Activities of Joint Stock Companies (the "JSC Law") and the Law of the Supreme Soviet of the RSFSR "On Enterprises and Entrepreneurial Activity," (the "Enterprise Law"), there are now seven types of business structures which may be registered by Western investors, including structures which date back to the Soviet era. 
Prior to negotiating a business relationship in Russia, one should analyze the various business structures to find one which best fits the foreign corporation's business plans and policies for entering a new foreign market. The decision made at this early stage can sow the seeds for the eventual success or destruction of the Western investor's business in Russia, as each form has compelling advantages and disadvantages. The major consideration is the closeness of the working relationship with any Russian partner, required by certain forms and not by others. Also, issues such as financing, taxes, timing of negotiations, and political and commercial risk must all be factored into the decision.

\section{A. EXISTING CORPORATE STRUCTURES}

\section{Accreditation}

The first form is based on Soviet laws of the 1970s, which allowed a foreign business to establish a representative office. A foreign business basically received an accreditation from a government ministry. This permitted a business to have a representative office in the USSR. This representative office, however, did not carry with it a distinct legal status separate from that of the parent company. Since the representative office was not a separate juridical entity apart from the parent company, it was liable for the debts of the parent (and vice versa). The representative office was also prohibited from direct involvement in contractual relations, except those necessary for the day-to-day running of the representative office. Therefore, it could represent the parent corporation, but the parent corporation was required to sign commercial contracts.

The accredited representative office is still in use today. However, the restrictions placed on such an office hinder the establishment of commercial relationships. The representative office, tied as it is to a supporting ministry, may not be a preferred method to establish presence in Russia should a company desire to have a commercial relationship with a number of private enterprises. We understand that new legislation is presently being drafted which will substantially amend the rights and processes relating to representative offices.

Presently, representative office applications are processed under Resolution No. 1074 of the USSR Council of Ministers, 30 November 1989. Firms must prove that they are "reliable partners" of Russian organizations and must have concluded previous business arrangements which have been of overall benefit to Russia. Foreign representatives are usually provided with two year permits which are regularly extended if the firm can show that its interests and those of Russia are being served by having an active representative office. The accrediting agencies can range from the Ministry of Foreign Economic Relations ("MVES") to the Russian Chamber of Commerce. Various ministries have indicated their ability to support the process; however, the MVES has the most experience in this matter.

The application for accreditation requires the corporate history of the foreign firm, information on its past commercial relationships with Russian entities and enterprises, and other supporting documentation, all appropriately translated, notarized and then legalized 
(stamped) at the Russian Embassy. The accrediting bodies are also permitted to request further details as to the aims and aspirations of the foreign firm.

After a lengthy period, during which the Russian ministries process the application and request and receive input from the previous Russian partners of the applying foreign firm, a letter or certificate of accreditation is provided. It details the scope of the accreditation, including the number of foreign citizens permitted to work in Russia and the period of accreditation.

Accreditation provides the foreign firm with legal standing in Russia, especially important with the Russian governmental authorities. It provides such benefits as multi-entry visas for staff and duty-free import of office furniture and equipment. In summary, an accredited office provides a foreign firm with an officially recognized independent beachhead in Russia. Its advantages include not having to have a Russian partner in the management of the operation and yet permitting the hiring of Russian nationals for office purposes. Its disadvantages include restrictions on contractual relationships which can be undertaken and the fact that it is not a legal entity separate from the parent corporation.

\section{Joint Ventures}

As of January 1987, joint ventures could be registered in the USSR. ${ }^{8}$ This permitted a foreign company with a Soviet partner to establish a separate legal entity. Initially, there were restrictions as to percentage of foreign ownership (maximum 49\%); however, as the economic reforms of the Perestroika period took root, these restrictions were rapidly abandoned. The Joint Venture approach evolved into the various joint stock companies and partnerships which are permitted under the new laws of the Russian Federation. The Joint Venture format is still being utilized in Russia by those who began their operations prior to the dissolution of the Soviet Union. Joint Ventures are an outmoded form of entity in Russia and are now being converted into Joint Stock Companies whenever Joint Venture charter documents are amended.

Joint Ventures with more than $30 \%$ foreign interests are still provided special privileges relating to taxation and currency exchange provisions. As recently as March 17, 1993, the Russian government arranged special concessions related to customs and duties for such entities. Joint Ventures are the form of corporate status with the longest recent history in Russia, so there has been a growing understanding of their attributes and abilities in Russian business and administrative structures. With a loosening of the percentage restriction on foreign ownership, the Joint Venture structure evolved to permit $100 \%$ foreign ownership.

\section{B. NEW CORPORATE STRUCTURES}

The following structures are allowed under new Russian Federation laws: 
(i) Partnership, with full liability, i.e. a general partnership. There is no limitation on the liability of the partners;

(ii) Mixed Partnership, with some partners being fully liable and others having restricted liability. General members are liable to the fullest extent for the partnership's liabilities and contributor members are liable only to the limit of their contributions;

(iii) Partnership, with limited liability for the partners. Identical for all practical purposes with a Joint Stock Company;

(iv) Joint Stock Company of a closed type (somewhat analogous to a Western style private corporation); and

(v) Joint Stock Company of an open type (somewhat analogous to a Western style publicly traded corporation).

\section{Partnerships}

The partnership structures all require a very intimate working relationship with Russians and have not had much popularity with foreign investors. This hesitancy is further compounded by the fact that Russian laws contemplating partnerships and Russian experience with such structures are in an embryonic stage.

\section{Joint Stock Companies}

The Joint Stock Company of a closed type is, however, the closest structure to a subsidiary or affiliated corporation as known in the West. The shares of a Joint Stock Company of a closed type may not be publicly traded but are transferable in accordance with the company's charter or the law and may be used as security for loans. (Other issues arise, however, such as registration of security.) If it were desirable to raise capital by a public offering, one would require an "open-type" Joint Stock Company and thereby involve a considerable number of new "securities" agencies in Russia. There is very little knowledge or understanding of publicly traded shares in Russia. Until there is a better body of law and administrative structure, we typically would not recommend an "open type" Joint Stock Company, unless the Russian side of the future company is familiar with its administrative requirements (i.e. MENATEP Group and other banking institutions in Moscow).

The Joint Stock Company of a closed type ("JSC") can be $100 \%$ foreign owned. According to present legislation, this type of structure receives the benefits which are bestowed on Joint Ventures with greater than $30 \%$ foreign investment. The JSC may engage in any form of commercial activity not forbidden by the laws of the Russian Federation. Under the JSC Law, commercial activity in sectors engaging in the extraction of raw materials require special permission from the Council of Ministers of Russia. However, contracted services for this sector not specifically related to the export and marketing of the raw materials fall outside this requirement. The JSC may have offices and branches within Russia and abroad. It may also have a share in the capital of other 
JSCs. The JSC has a limited liability structure; thus, under Russian law, the shareholders of the JSC are only liable to the extent of the contributions made to the JSC's capital. There can be one or more founders of a JSC. The shares of the company can be transferred from one entity to another only with the agreement of a majority of the shareholders, unless otherwise specified in the Charter of the company.

\section{CREATION OF A JOINT STOCK COMPANY}

\section{A. PROCEDURE}

The procedure for creating a JSC is simple yet, in true Russian fashion, rather bureaucratic. The following is the basic procedure for creating and registering the company in Moscow.

The procedure for state registration of a JSC which has $100 \%$ foreign ownership is stipulated in the RSFSR Law on Foreign Investment and a variety of instructions and decrees from various ministries. Registration is presently with the Committee on Foreign Investments ${ }^{9}$ which is under the auspices of the Ministry of Finance. This committee has recently been reformed into the Russian Agency for Cooperation and Development ("RAMSIR").

First, one requires copies (preferably three) of various documents including Articles of Incorporation, the registration certificate of the Canadian corporation, and a letter from an established bank recommending the company and stating that the company is reputable, that it has carried on business for a specified number of years and that it is a valued client. These documents must be translated into Russian and both the English and Russian versions stamped/notarized by the Russian Embassy in Ottawa.

Second, a Charter of the JSC must be drafted and approved by the founding stockholder. The Charter is a document somewhat similar in form to the original Joint Venture agreements in Russia. There is a requirement to stipulate a Charter Fund (initial capital fund) of at least 10,000 rubles (less than $\$ 15$ US at the new commercial exchange rates). It should be noted that Charter Funds over 50 million rubles require special authorization from the state body concerned with anti-monopolistic measures, and that a Charter Fund of over 100 million rubles requires special approval from the Council of Ministers of Russia. It is recommended that the Charter Fund be kept to a minimum, as there is also a requirement that one half of the Charter Fund be paid within the first $\mathbf{3 0}$ days after temporary registration of the JSC and the remainder within the first year of operations. There may be favourable tax implications for a larger Charter Fund; however, this would be a subject for further discussions.

Third, there is a requirement to procure a "legal address" in Moscow as the city of registration. This is a somewhat convoluted process, as one requires a Russian organization to write a letter supporting or guaranteeing the legal address for the new 
company. Presently in Moscow there are a number of companies willing to provide their address for a fee.

Fourth, one needs to provide a sealed (corporate seal of the parent company) version, translated into Russian, of a special decision of the managing board of the companies which are founders of the JSC. This should include statements regarding the nomination of the officers of the JSC, acceptance of the Charter and the appointment of the Director General.

Fifth, a diagram of the proposed corporate seal of the new JSC is required.

Sixth, a written application, in Russian, describing the documents and requesting the Moscow Central Registration Chamber to register the company.

If the above documents are in order, one procures, for a nominal fee, a temporary certificate of registration. The temporary certificate is adequate to get one started on a variety of calls to procure various administrative approvals. First, one goes to the State Committee of Statistics to receive a letter with four codes. These codes are the basis for further registration numbers for approval for foreign trade activities. Then one goes to (a) the Ministry of Internal Affairs (the police) in order to register the Seal, (b) the tax authorities, (c) the Pension Fund, (d) the Employment Fund (the latter two if you wish to employ Russians, to obtain registration numbers for their social benefits) and (e) the bank to open a ruble account. One should then pay into the account the $50 \%$ of the Charter Fund as noted above and receive a certificate stating that this has been done. The penultimate step is a visit to RAMSIR (presently under the combined jurisdiction of the Ministry of Finance and Ministry of Economics) and, for another nominal fee for fast service (plus or minus two weeks), the receipt of their permission. Last but not least, with evidence that the Charter Fund has been fully capitalized, one goes to the Moscow Central Registration Chamber and receives the final permanent certificate of registration.

The above process can be rather lengthy, but yet if shepherded along, can be completed in one to two months. It should be noted that once a temporary certificate has been issued, the JSC can begin commercial operations.

Under the Mineral Resources Law and under the draft law on Oil and Gas, licenses for exploration, production and operations can also be purchased and these can provide permission to undertake operations in Russia. In brief, licenses may permit foreign businesses to operate in Russia for as long as 20 to 25 years. However, a registered Russian business entity such as a JSC provides an identity which is very beneficial for foreign corporations wishing to operate in Russia.

\section{B. HOW TO ESTABLISH THE DEAL}

The process to establish the basic business arrangement in Russia for energy related projects involves various jurisdictions and authorities. It must be noted that the processes for establishing clear and defensible legal title and authorizations in the Russian Federation are undergoing constant change. Each level of government, from local to 
federal must be dealt with. The promulgation of new laws such as the Law No. 2395-1 "On Mineral Resources of the Russian Federation", 5 May 1992 (the Mineral Resources Law) and the Decree "On the Rules of Export of Strategically Important Raw Materials," which renew central authority over the export of hydrocarbons, must be taken into consideration.

The initial step is to establish and register a JSC. In order to register a JSC which is specifically involved in energy projects, a detailed feasibility study needs to be submitted to both the local registering authorities and to the central government in Moscow. The feasibility study will form the basis for the approval process for the project. The study includes both the technical and business parameters of the project. With the registration documents, the feasibility study and the supporting documents from the local Russian partners in hand, one embarks upon the required approval process. This process includes dealing with the Expert Commission of the Ministry of Fuel and Energy, the InterDepartmental Commission Joint Ventures, which consider applications for export tariffs exemptions, and a host of other bureaucratic bodies, such as Rosgeolcom of the Ministry of Geology.

\section{LOCAL GOVERNMENT REGULATION}

The local level of the approval process includes a requirement to procure letters of support from the authorities at the "rayon" and "oblast" levels. Permits which grant such rights as access to the sites and the use of resources such as water, electricity and other infrastructural items must be requested from the local governments. Agreements for the use of housing and office space should be negotiated with the local authorities. The local governments have been given significant taxing powers, and a negotiated settlement outlining the extent of their involvement in the taxation of an enterprise is recommended. An example of local autonomy and therefore input by a local government can be seen in Decree No. 1082 of the Russian President, 23 December 1992, which in part transfers the ownership of enterprises and organizations engaged in oil and gas production to the Komi Republic, and makes $70 \%$ of all payments such as excise and profit tax payable to the Komi Republic for the use of Komi's exhaustible natural resources. This input from local government bodies is important as it relates to spending for medical facilities, schools and other social infrastructural needs of the local population. There will be environmental concerns and issues relating to the indigenous peoples of the area which must also be resolved at the local level. The negotiations with the regional, city, rayon and oblast levels of government should be undertaken at the same time as negotiations with the various ministries and sub-groups of the federal level of the Russian Federation. The local levels of government must be willing to provide letters of endorsement for the projects to the Russian Committee for Natural Resources as established in the Mineral Resources Law.

\section{RUSSIAN FEDERATION GOVERNMENT AUTHORITIES}

The various authorities which need to be dealt with include the following Ministries and committees: The Committee on Foreign Investments (under the Ministry of Finance), The Ministry of Fuel and Energy, the Ministry of Finance, the Expert Commission of the Russian Federation Industry of Fuel and Energy for Considering Applications for 
Establishing JV's, the Ministry of Foreign Economic Relations, the Council of Ministers (on large projects dealing with significant hydrocarbon reserves), the Ministry of Economics and the Ministry of Ecology and Natural Resources.

The Russian Committee for Geology (Rosgeolcom), created to oversee the issuance of licenses under the Law on Underground Resources of the Russian Federation, has the authority to grant exploration licenses for periods of 20 to 25 years depending on the requirement for geological exploration. Extraction licenses are for a maximum of 20 years. The regulations and detailed procedures to establish these licenses continue to be amended. The present method to gain licensed rights is to deal with this committee as well as with the Russian Fuel and Energy Ministry Expert Commission under the jurisdiction of the Ministry of Fuel and Energy. The draft law on Oil and Gas has been released; however, one cannot easily speculate on the final outcome of the draft, except to state that this law will probably assist in the clarification of rights to hydrocarbon deposits. The draft law stipulates that the oil and gas resources of the Russian Federation are under the joint jurisdiction of the central government and the republics. Licenses will be required for the use of oil and gas resources and a variety of payments, bonuses and taxes will need to be paid to the various government authorities. In order to receive a license, negotiations, competitions or both may be required by the licensing body. Article 13 of the present Mineral Resources Law states, "licenses to use mineral resources shall be granted on the basis of competition and auction." It must be noted that the Russian government, the Russian parliament, the local governments and the production associations are in a constant state of re-negotiation concerning the procedures surrounding the issuance of licenses. It is clear that each project of any magnitude requires individual sets of negotiations in order to arrive at unique solutions.

The Ministry of Fuel and Energy, headed by Minister Shafranik, has increased its authority over foreign investments in the energy field over the last few months. Investors must gain the support of its expert technical committees which review feasibility studies, as well as of the Committee of the Oil Industry. On larger projects, where approval of the Council of Ministers of the Russian Federation is required, the Ministry of Fuel and Energy's formal support of the project is crucial.

RAMSIR must provide its approval prior to the registration of any JSC or Joint Venture dealing in the field of energy production.

The Ministry of Finance is the authority with which the Canadian company should review its proposed taxation structure relating to export tax exemptions, hard currency conversions and any possible special concessions. Decree No. 629 of the President of the Russian Federation "On the Partial Modification of the Procedures for the Sale of Hard Currency and the Collection of Export Duties," 14 June 1992, is enforced by departments under the Ministry of Finance and the Central Bank of the Russian Federation. Exemptions from the export tax as presently constituted require the support of both these institutions.

The Ministry of Foreign Economic Relations has been empowered under Decree No. 628 of the President of the Russian Federation "On the Export of Strategically 
Important Primary Commodities," 14 June 1992, to oversee export licenses for hydrocarbons. There are two types of export licenses, a general license provided for one year covering multiple transactions, and a single license for one transaction within one year of the date of issuance. One must also work with the Customs Committee in order to procure such a license.

The Ministry of Economics of the Russian Federation as well as the Ministry of Ecology and Natural Resources also have residual influence in the successful registration of energy companies, depending on the size of the project and the ecological issues which may affect the location where the company proposes to operate. According to a decree of June 9,1992 , there is a requirement that all enterprises with foreign ownership pass an ecological examination prior to receiving the authorization to commence operations.

\section{RUSSIAN TAX FRAMEWORK}

The following is a brief overview of selected taxation issues to be considered when attempting to operate in the former Soviet Union. As each country emerges as an independent entity, the tax aspects become unique for each area and generalized rules must be reviewed prior to gaining any certainty as to their enforceability.

\section{A. FORMS OF TAXATION}

\section{Profits Tax}

Tax on business and "entrepreneurial activity" is governed by the Law of the Russian Federation No. 2116-1 regarding tax "On the Profit of Enterprises and Organizations," 27 December 1991 (the "Profits Tax"). Shortly after this law came into force, the Government of the Russian Federation passed a second tax law, "On Income Tax from Enterprises," which was intended to supplant the Profits Tax but which has not yet been implemented. There have been suggestions that the income tax law will be introduced before January 1, 1994. Most likely, the second income tax law will fade away without being implemented.

Under the Profits Tax, enterprises formed under Russian law are taxed on their worldwide taxable profits. Non-Russian entities are taxed on income earned in Russia through a permanent establishment.

The Profits Tax imposes a tax of $32 \%$ on a taxable base calculated in a manner similar to that of most Western countries. The starting point for calculating taxable profit is the profit disclosed by the company's statutory accounts. Russia's statutory accounting rules have evolved from cash-basis accounting to accrual accounting and recent changes have brought these rules closer to conformity with Western practices. Profits from sales of goods, services, and property, and profits from non-sales operations are reduced by the expenses associated with such activities. "Profits" are the difference between the amount received from the sale, exclusive of taxes, less the cost of production. The following significant exceptions from typical Western tax deductions may cause taxable profits to be overstated, according to Western methods, thus resulting in a higher effective tax rate: 
(i) deductibility of interest expense is severely restricted; and

(ii) wages paid by the taxpayer in excess of four times the official Russian minimum wage (currently at 2250 rubles, or about $\$ 3.00$ U.S. per month) are not deductible.

The restrictions on deductibility of wages do not apply to $100 \%$ foreign owned Russian legal entities or permanent establishments of foreign legal entities. As well, the U.S. has been able to negotiate an exception for Russian companies with at least $30 \%$ U.S. investment which allows these companies to deduct labour expenses. The U.S. - Russian tax treaty has been signed but still remains to be ratified by the U.S. Senate. Joint ventures established earlier may have qualified for statutory tax holidays or have been able to negotiate them. Although such holidays have generally been eliminated, Russia's autonomous republics, which are allocated a portion of tax revenues, have been authorized to grant exemptions from or reductions in the rate of tax revenue to which they are otherwise entitled. Such concessions are granted on a case by case basis and are yet another reason for having local authorities onside when negotiating a deal.

Companies may generate a Reserve Fund in profitable years of up to $25 \%$ of the Charter Fund as a protection against future anticipated losses. Transfers to a Reserve Fund are deductible.

\section{Value-Added Tax ("VAT")}

The VAT was introduced with effect from January 1, 1992, and as of January 1 of 1993 , the rate was reduced from $28 \%$ to $20 \%$ on most goods. It is levied on the cost of all goods purchased and services rendered in Russia but does not appear to apply to exports of goods or services. The import of goods will attract VAT from February 1, 1993. As of January 1, 1993 the law permits recovery of VAT in respect of items where the net cost was charged to production and distribution and on the purchase of fixed and intangible assets over a two year period from the date of first use or registration. The process to recover the VAT, however, is an administrative nightmare in the newly emerging Russian tax bureaucracy.

\section{Royalty}

For crude oil, the royalty rate is $8 \%$ on the "value" produced. Although unclear, the "value" appears to be world-market rate of oil.

\section{Export Tax}

In addition to obtaining an export license, it is necessary to pay export duties on certain goods. The current export tax rate for crude oil is 21 ECU (European Currency Units) per ton, or approximately $\$ 4.20$ U.S. per barrel. Joint ventures registered prior to 1992 are exempt from this tax until they recoup their original investment, but since 1992, exemptions have been granted on a case-by-case basis. New decrees recently promulgated have shown a willingness by the Russian authorities to extend the exemption for certain 
post-1992 foreign JSC's. Companies wishing to revisit their original joint venture format to take advantage of newer and more flexible business structures must consider the possibility of losing this tax exemption.

\section{Import Duties}

Import duties are imposed on a number of listed goods. However, equipment imported for use on a project, in Russia for less than a year, is exempt from import tax as are goods imported by a foreign investor for its contribution to the Charter Fund of a Russian company.

\section{Mandatory Currency Conversion}

Russian law requires companies that earn hard currency to convert half of that amount into rubles, at the market rate. An enterprise with greater than $30 \%$ foreign investment can convert and, usually, immediately reconvert these amounts into hard currency, limiting its risk of currency fluctuation but still being forced to pay the related commissions and transactions costs.

\section{B. TAX CONSIDERATIONS WHEN REPATRIATING FUNDS}

\section{Russian Withholding Tax}

Russian tax law imposes a $15 \%$ withholding tax on dividends or profits paid by Russian entities to non-residents. This tax may be reduced if the non-resident recipient falls under the umbrella of an international tax treaty. The Russian Federation has adopted most of such treaties to which the USSR had been a party. The Canada-USSR Income Tax Agreement, $1985^{10}$ is an example of this which continues to apply. The U.S. has been successful in negotiating a revised, and favourable, double taxation treaty directly with the Russian Federation. It is expected to take effect late in 1993.

The Canada-USSR Income Tax Treaty limits the rate of withholding tax which may be levied on dividends paid to a beneficial owner resident in Canada to $15 \%$. Many other treaties have limits below $15 \%$, and some have reduced this amount to $0 \%$. For instance, the new treaty with the U.S. reduces this amount to $5 \%$, and the treaty with Cyprus to $0 \%$.

Many Canadian companies have opted to channel Russian investment through intermediary companies established in Cyprus. As Cypriot residents, these Newcos are not subject to Russian withholding tax but are required to pay a $4.25 \%$ Cypriot tax on income. There are no further withholdings when flowing the funds through to the Canadianresident parent. 
Cyprus is not the only country which has a $0 \%$ withholding tax agreement with Russia; however, it is one of the most commercially sophisticated of those countries. In order for the Cypriot company to fall outside the definition of a resident of Canada for Canadian tax purposes, management and control of the Cypriot company must not reside in Canada. Therefore, it is important to establish such a company in a relatively stable environment which has appropriate infrastructure. Many Canadian investors in Russia have determined that Cyprus meets these requirements.

\section{Taxation of Dividends in Canada}

Canadian tax treatment will depend on whether the Russian (or Cypriot or other) company paying dividends qualifies as a "foreign affiliate" under Canadian tax law. A "foreign affiliate" is a corporation not resident in Canada in which the Canadian taxpayer holds, directly or indirectly, at least $10 \%$ of the outstanding shares of all classes of the corporation. ${ }^{11}$ Furthermore, tax treatment will depend on how the dividend was paid out by the foreign affiliate. General Canadian tax considerations should be reviewed.

\section{CHECKLIST}

This paper has reviewed the Canadian-Russian business environment and the general legal aspects of establishing a business entity in Russia. It has provided an overview of the establishment of business arrangements for energy projects. What follows is a practical issues list which business people should review and develop prior to venturing into Russia.

These issues, in brief, are:

1. Contracting partners - Russian government and private enterprises

- relationship with local authorities and central authorities; and

- Canadian company's legal structure - through Cypriot subsidiary or other entity?

2. Local organization structure

- co-ordination between Russian operations of Canadian company and

Canadian head office

3. Payment issues

- hard currency and ruble issues

4. Banking and finance issues

- forced currency conversions

- which banks to deal with

- escrow accounts

- external banking support

5. Taxation - Russian

6. Taxation - International 
7. Transport of Western Goods/Transportation

- insurance issues

- security

- customs

8. Transfer of technology

- effectiveness of patent/copyright laws

- confidentiality issues

- non-disclosure agreements and enforcement

9. Accounting

- local and international rules

10. Russian government structures

11. Local labour usage

- connections to appropriate ministries

- labour law

- compensation issues

12. Expatriate labour

- visas

- living conditions, site staff accommodation

- orientation and employee relations policies

13. Local construction codes

- including environmental concerns

- local standards versus international standards

14. Local supplies of goods and services

- policy

15. Security

- reality (ability to pay in local currency)

16. Insurance

- of personnel

- of equipment

- directors' and officers' liability

- political risk

- investment coverage (EDC)

17. Ownership

- security and registration

- liens

18. Western company guarantees

- what has been held out

- perceptions versus reality

19. Arbitration

- dispute settlement provisions

\section{CONCLUSION: RUSSIA'S CHANGING LANDSCAPE}

On May 6, 1993, the Presidium of the Council of Ministers approved a new law "On Joint Stock Companies." It is now with the Supreme Soviet for final approval. The document will not be made public until that approval has been granted, but it will certainly have a continuing impact on Canadians doing business in Russia. 
The emergence of a Western-based market oriented system with Russian cultural and historical overlays will take years to evolve. What is clear today is that this evolution will develop new opportunities for western businesses operating in the former Soviet Union. 